\title{
Nutritional and reproductive strategies in a chemosymbiotic bivalve living in a tropical intertidal seagrass bed
}

\author{
Matthijs van der Geest ${ }^{1, *}$, Amadou Abderahmane Sall ${ }^{2}$, Sidi Ould Ely ${ }^{3}$, \\ Reindert W. Nauta ${ }^{1}$, Jan. A. van Gils ${ }^{1}$, Theunis Piersma ${ }^{1,4}$ \\ ${ }^{1}$ NIOZ Royal Netherlands Institute for Sea Research, PO Box 59, 1790 AB Den Burg, Texel, The Netherlands \\ ${ }^{2}$ Mauritanian Institute for Oceanographic Research and Fisheries (IMROP), BP 22, Nouadhibou, Mauritania \\ ${ }^{3}$ Parc National du Banc d'Arguin, BP 5355, Nouakchott, Mauritania \\ ${ }^{4}$ Chair in Global Flyway Ecology, Animal Ecology Group, Centre for Ecological and Evolutionary Studies (CEES), \\ University of Groningen, PO Box 11103, 9700 CC Groningen, The Netherlands
}

\begin{abstract}
Sulphide-oxidizing endosymbiont-bearing bivalves often dominate the infauna of seagrass-covered sediments, where they control sulphide levels and contribute to carbon cycling by feeding on chemosynthetically fixed carbon and suspended particulate organic matter (SPOM). Previous studies from temperate habitats suggest that SPOM availability may regulate growth and reproduction, since SPOM may be of greater nutritional value than the material provided by bacterial endosymbionts. To examine if changes in diet correlate with body condition and reproductive activity, we studied seasonal patterns in somatic and gonadal investment and gametogenic development in relation to nutrition in the endosymbiont-bearing bivalve Loripes lucinalis in seagrass-covered intertidal flats at a tropical study site (Banc d'Arguin, Mauritania). Carbon stable isotope analysis revealed clear seasonal cycles in the relative heterotrophic contribution to the diet of Loripes, with mean monthly values ranging from $21 \%$ in March to $39 \%$ in September. Seasonality was also observed for size-corrected body and somatic mass, both increasing from March to October, suggesting food limitation during winter. In contrast, Loripes exhibits a semiannual reproductive cycle characterized by major spawning events during both January-February and July-August. Growth and gametogenic development seem to especially require supplemental heterotrophic nutrition from June to January. Thus, the ability to shift to heterotrophic feeding contributes to growth, reproductive output and survival in Loripes, with downstream effects on population dynamics and seagrass functioning.
\end{abstract}

KEY WORDS: Bivalvia · Mixotrophy · Stable isotopes · Seasonality · Reproductive cycle • Life history $\cdot$ Sulphide $\cdot$ Seagrass

\section{INTRODUCTION}

Nutritional associations between intracellular sulphide-oxidizing bacteria and marine invertebrates were discovered in deep-sea hydrothermal vents by Felbeck et al. (1981). A few years later, they were also discovered in more accessible habitats such as shal-

${ }^{*}$ Corresponding author: matt.van.der.geest@gmail.com low-water sediments (e.g. Cavanaugh 1983, Fisher \& Hand 1984, Schweimanns \& Felbeck 1985). In this association, the invertebrate host favours bacterial chemosynthesis by facilitating the supply of sulphide, $\mathrm{CO}_{2}$ and oxygen. In exchange, the bacterial symbionts fix carbon, which supports the growth and maintenance of host biomass (Stewart et al. 2005). 
Among chemosymbiotic organisms, bivalves of the Lucinidae family are the most species-rich group. Lucinids occupy the greatest variety of habitats and are geographically the most widespread $\left(60^{\circ} \mathrm{N}\right.$ to $55^{\circ} \mathrm{S}$ ) (Taylor \& Glover 2006). Their sulphideoxidizing symbiosis is probably obligate, and this may explain why lucinids often dominate the infauna of sulphide-rich anoxic sediments of seagrass meadows (van der Heide et al. 2012). Here, the bacteria-lucinid bivalve association forms one of the main components of the intertidal benthic community - with top-down effects on sediment biogeochemistry and ecosystem functioning (van Gils et al. 2012) through the reduction of toxic sulphide levels, thereby enhancing seagrass production (van der Heide et al. 2012); and bottom-up effects through the conversion of $\mathrm{CO}_{2}$ directly into consumer biomass, which then becomes available to predators such as wintering molluscivore shorebirds (van Gils et al. 2012, 2013). Like most endosymbiont-bearing bivalves, lucinid bivalves have a mixotrophic diet, feeding on carbon metabolites provided by their endosymbiotic bacteria, and on suspended particulate organic matter (SPOM) from the water column (Le Pennec et al. 1988, Cary et al. 1989, Johnson et al. 1994, Duplessis et al. 2004, Rossi et al. 2013). Despite their important ecological functions in seagrass ecosystems, general principles of the reproductive biology and energetics of lucinid and other endosymbiont-bearing bivalves remain poorly understood.

In bivalves, as in other organisms, the timing and duration of reproductive activity and spawning are generally believed to be determined by an interaction between exogenous (environmental) and endogenous (genetic and physiological) factors (reviewed in Sastry 1979). Two of the main exogenous factors commonly cited as reproductive timing cues in heterotrophic bivalves are temperature and particulate organic food availability (Sastry 1979, MacDonald \& Thompson 1986, Santos et al. 2011).

Stable carbon isotopes have proven to be a useful tool to study temporal and/or spatial variability in the relative importance of chemosynthetic and photosynthetic sources of carbon assimilated by endosymbiont-bearing bivalves (Spiro et al. 1986, Conway et al. 1989, Dando \& Spiro 1993, Rossi et al. 2013). Fractionation of stable carbon isotopes $\left(\delta^{13} \mathrm{C}\right)$ is limited to about $1 \%$ per trophic level (Peterson \& Fry 1987), and thus it can be used to identify carbon sources in the diet of consumers (Fry 2006). Consequently, analysis of $\delta^{13} \mathrm{C}$ signatures of host tissues revealed that the relative importance of particulatederived nutrition in chemosymbiotic bivalves can vary between 2 and $74 \%$ (Cary et al. 1989, Conway et al. 1989, Dando \& Spiro 1993, Johnson et al. 1994, Rossi et al. 2013). This flexible feeding mode may help chemosymbiotic bivalves survive in environments where the concentration of particulate food, sulphide and oxygen varies in space and/or in time (Dufour \& Felbeck 2006, van Gils et al. 2012, Rossi et al. 2013).

Although the nutritional role of heterotrophy in endosymbiont-bearing bivalves is poorly understood (Pile \& Young 1999), there is some indirect evidence from temperate littoral and deep-sea habitats that seasonality in SPOM availability may regulate growth rate and reproductive activity in endosymbiont-bearing bivalves (Le Pennec et al. 1995, Pile \& Young 1999, Le Pennec \& Beninger 2000, Dixon et al. 2006, Tyler et al. 2007). SPOM is considered to be more nutritionally and energetically rich than food provided by endosymbiotic bacteria (Le Pennec et al. 1995, Pile \& Young 1999, van Gils et al. 2012). The synchronization of energetically costly gamete production and breeding to periods of increased SPOM availability may therefore be an evolutionary adaptation: adults can profit from supplementary nutrition, which will increase their reproductive output and survival prospects, while their offspring can profit from optimal food conditions when born, which will increase their survival prospects.

Seasonal fluctuations in environmental factors, including temperature, photoperiod, salinity and particulate food availability are present in virtually all littoral habitats (Le Pennec \& Beninger 2000), but they are thought to be considerably less pronounced in the tropics than in other regions. As a result, tropical marine invertebrates often show more continuous gametogenic activity and spawning (Sastry 1979, Fournier 1992, Pouvreau et al. 2000). If variability in SPOM availability indeed regulates the reproductive cycle of chemosymbiotic bivalves, then one would predict less pronounced seasonality in feeding behaviour, and as a result, more continuous gametogenic activity and breeding in tropical chemosymbiotic bivalves.

The littoral endosymbiont-bearing lucinid bivalve Loripes lucinalis (Lamarck, 1818; synonymized with Loripes lacteus, for which symbiont $16 \mathrm{~S}$ sequences are in GENBANK but unpublished) is a mixotrophic species (Le Pennec et al. 1988, Johnson et al. 1994) covering a wide geographical range (from $55^{\circ} \mathrm{N}$ to $19^{\circ} \mathrm{N}$ ) from the British Isles in the north to Mauritania in the south. Previous studies investigating the reproductive cycle in a temperate littoral Loripes lucinalis population showed clear seasonality in 
gametogenic activity and breeding, with spawning events occurring in May and (to a lesser extent) between November and December, both of which were preceded by phytoplankton blooms (Le Pennec et al. 1995).

Here, we examine the degree of 'tropical seasonality' in diet, growth (measured as an increase in sizecorrected body mass), somatic and gonadal investment, and gametogenic development of Loripes lucinalis (hereafter Loripes) at the southern border of its distributional range - the tropical seagrasscovered intertidal flats of Banc d'Arguin, Mauritania $\left(20^{\circ} \mathrm{N}\right)$. Assuming that SPOM availability is rather constant at tropical latitudes, we predict little seasonality in feeding behaviour, and as a result, continuous gametogenic activity and breeding in chemosymbiotic Loripes from tropical Banc d'Arguin. We tested this prediction by analyzing: (1) the degree of heterotrophic feeding by following changes in Loripes carbon isotopic signatures throughout the year; and (2) the degree of seasonality in reproductive activity by assessing the seasonal patterns in gonadal mass and gametogenic development. Furthermore, we investigated reproductive strategies in Loripes by analyzing mass allocation to growth and reproduction by following changes in body, somatic and gonadal cycles throughout the year. In addition, we investigated if environmental conditions (i.e. temperature, precipitation) regulate the degree of heterotrophic feeding, growth and reproductive activity in Loripes, and if temporal patterns in heterotrophic feeding correlate with periods of growth and reproductive activity in Loripes.

\section{MATERIALS AND METHODS}

\section{Study area}

The study area, located near the coastal village Iwik $\left(19^{\circ} 52.42^{\prime} \mathrm{N}\right.$, $16^{\circ} 18.50^{\prime} \mathrm{W}$; Fig. 1), is an accessible part of the intertidal area of the nationally protected Banc d'Arguin off the coast of Mauritania. This ecosystem is characterized by tidal flats densely covered by seagrass (mainly Zostera noltii Hornem.; Wolff \& Smit 1990). The intertidal flat area is a major wintering site for migrating shorebirds (Altenburg et al. 1982) and is also renowned as a nursery area for fish (Jager 1993). Being adjacent to the Sahara desert, the Banc d'Arguin does not receive freshwater inflow from rivers, and precipitation is limited to occasional thunderstorms that occur at irregular intervals - sometimes several years apart (Wolff \& Smit 1990). In the Iwik region, seawater temperature varies between $20^{\circ} \mathrm{C}$ in winter and $30^{\circ} \mathrm{C}$ in summer (Wolff \& Smit 1990). The tide is semi-diurnal and the tidal range is 1.5 to $2 \mathrm{~m}$.

Loripes lucinalis is the most dominant bivalve in the reducing sediments of the intertidal seagrasscovered flats of Banc d'Arguin (van Gils et al. 2013, Ahmedou Salem et al. 2014) with densities up to 4000 ind. $\mathrm{m}^{-2}$ (van der Geest et al. 2011). In these sediments, they live within the network of rhizomes of Zostera noltii at depths of 0 to $10 \mathrm{~cm}$, a zone of high sulphide concentrations (van Gils et al. 2012).

\section{Environmental parameters}

We collected environmental data (sediment and air temperature, and precipitation amounts) during our study period (October 2009 through January 2011) and in the preceding 9 months (January 2009 to October 2009). Sediment temperature $\left({ }^{\circ} \mathrm{C}\right)$ at $2 \mathrm{~cm}$ depth was recorded every 30 min during most of the study period (from 1 January 2009 to 11 October 2009, and from 14 December 2009 to 7 October 2010) with a logger (Stow-Away® TidbiT®). Mean daily air temperature $\left({ }^{\circ} \mathrm{C}\right)$ and total monthly precipitation $(\mathrm{mm})$ were obtained from the closest weather station at Nouadhibou, $134 \mathrm{~km}$ northwest of the study site (via www.tutiempo.net/en/Climate/Nouadhibou/012009/614150.htm).
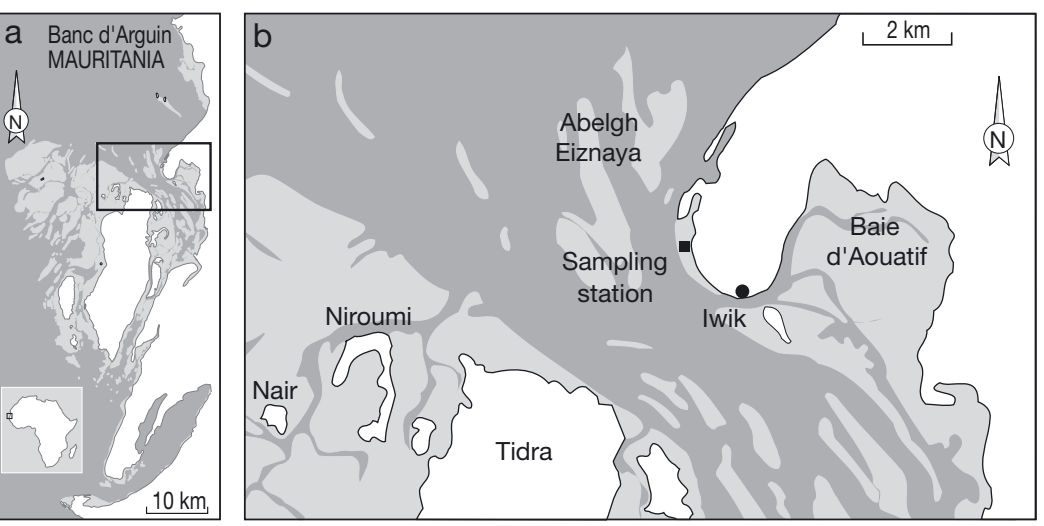

Fig. 1. Map of (a) the Banc d'Arguin, Mauritania, West Africa. White = land, light grey = intertidal area, dark grey = subtidal area; and (b) our study area, near the coastal village Iwik (black circle), with the position of the sampling station $\left(19^{\circ} 53.540^{\prime} \mathrm{N}, 16^{\circ} 18.856^{\prime} \mathrm{W}\right.$; black square) in an intertidal Zostera noltii bed 


\section{Sampling}

Loripes was collected at an intertidal seagrass (Zostera noltii)-covered site in the vicinity of Iwik $\left(19^{\circ} 53.540^{\prime} \mathrm{N}, 16^{\circ} 18.856^{\prime} \mathrm{W}\right.$; Fig $\left.1 \mathrm{~b}\right)$. The sampling site covered an area of $625 \mathrm{~m}^{2}$ that remains emerged for $50 \%$ of the tidal cycle, and can be characterized by muddy sediment with a relatively high percentage of silt/clay (for sediment characteristics at our study site see Text S1 in the Supplement at www.int-res.com/ articles/suppl/m501p113_supp.pdf).

Sediment cores were collected once each month from October 2009 to January 2011 to acquire a random sample of Loripes across all available size classes. Care was taken to maintain a distance of $5 \mathrm{~m}$ between monthly sampling sites. Following procedures published elsewhere (van der Geest et al. 2011), sediment cores (15 cm diam.) were taken to a depth of $20 \mathrm{~cm}$ and sieved over a $1 \mathrm{~mm}$ mesh. From each sieved benthic sample, all Loripes individuals were sorted within $24 \mathrm{~h}$ and preserved in boraxbuffered formalin (4\%). Each month, a sub-sample of 10 to 36 ind. was selected haphazardly, covering the entire growth range.

\section{Body mass and reproductive cycle}

To identify the reproductive cycle of Loripes, we applied the method of Johnson et al. (1996), who used mass loss in the gonad-digestive gland complex (GD) as an indicator of spawning periods in Loripes, because the gonad and digestive gland are intertwined and cannot easily be separated.

For each specimen, shell length $(L)$, shell height $(H)$ and shell thickness $(T)$ was measured with electronic calipers (precision $0.1 \mathrm{~mm}$ ), after which bivalves were opened and gonad-digestive gland tissue was separated from the remaining somatic mass under a binocular microscope (10x). A smear sample of the gonad tissue was examined microscopically to determine sex and reproductive stage of each individual using a semi-quantitative descriptive scale modified from Guillou et al. (1990):

'Indifferent': no gonad tissue visible. This has 2 possible explanations: (1) adults with recuperating gonads after spawning events, or (2) immature juveniles.

'Developing 1': gonad tissues visible, but it is very difficult to distinguish sexes. No mature elements are present.

'Developing 2': gonad tissues are evident and sexes can be distinguished. Gametes are abundant, and pedunculate oocytes are present.
'Ripe': gonad tissue with spermatozoa grouped into rings or spherical oocytes with a thick envelope. Spawning is imminent.

'Spent': gonads are empty and thin. Coexistence of cells being reabsorbed and mature cells.

After microscopic analysis, the smear sample was carefully added to the remaining GD tissues and dry mass (DM) was determined to the nearest $0.01 \mathrm{mg}$ for both GD and somatic tissues by drying for $48 \mathrm{~h}$ at $60^{\circ} \mathrm{C}$. To follow allocation in somatic versus GD mass, the somatic mass index (SMI) and the gonadal mass index (GMI) were estimated as the DM of the soma or GD, respectively, divided by a proxy of shell volume calculated as $L \times H \times T$ to allow comparison between animals of different sizes (Santos et al. 2011).

Body mass indices are generally considered to indicate the seasonally changing nutritional status of bivalves (reviewed in Crosby \& Gale 1990). In order to determine body condition, the body mass index (BMI) was calculated as the total body DM (soma + GD) divided by $L \times H \times T$ (Honkoop \& Beukema 1997, Santos et al. 2011).

Immature animals have smaller gonads than mature animals, and the cycles of their gonad weights and gametogenesis etc., may well differ from mature Loripes (Grant \& Tyler 1983). Immature animals should thus be excluded from analyses of the timing of reproductive activity. To determine size at first maturity, we plotted the percentage of sexed animals (e.g. those animals with reproductive cells) against shell height. Subsequently, we excluded Loripes smaller than the obtained minimum size at which the majority of Loripes could be sexed from further analyses.

Because individuals that have reached size at maturity do not necessarily reproduce, we used the specimens collected during the defined spawning pe$\operatorname{riod}(\mathrm{s})$ to identify the minimum shell height at which the majority of the Loripes population was in 'spent' stage, here defined as the size at first reproduction.

\section{Carbon stable isotope analysis}

For mixotrophic endosymbiont-bearing bivalves, knowledge of both the bacterial and host carbon isotope signatures and the carbon isotopic composition of the SPOM-based food source is a prerequisite for quantifying the extent of nutritional coupling between the host and its endosymbionts (Conway et al. 1989, Rossi et al. 2013).

On 2 occasions in May 2008, SPOM (a mixture of phyto- and zooplankton with some seston/detritus/ 
suspended benthic diatoms) was collected from the water column on the incoming tide, using a plankton net with a mesh size of $50 \mu \mathrm{m}$ that was deployed behind a slow-moving boat adjacent to our intertidal sampling station (Fig. 1b). The collected SPOM was diluted in $10 \mathrm{l}$ of GF/F-filtered (0.7 $\mu \mathrm{m}$ porosity) seawater, and this solution was sieved over a $300 \mu \mathrm{m}$ sieve to eliminate large zooplankton and detrital particles. The seawater containing sieved SPOM was filtered on pre-combusted GF/F filters ( $0.7 \mu \mathrm{m}$ porosity) under a moderate vacuum. Filters were stored frozen $\left(-20^{\circ} \mathrm{C}\right)$ until stable carbon isotopic analysis.

To obtain the $\delta^{13} \mathrm{C}$ signature of the endosymbiotic chemoautotrophic bacteria located in the gills of Loripes, 20 Loripes clams (measuring between 7 and $11 \mathrm{~mm}$ in shell height) were haphazardly collected at our Zostera-covered study site in May 2008, using the same sampling methodology as described above (see Sampling section). Subsequently, the clams were dissected to separate the endosymbiont-bearing gills from the remaining tissues.

To study the degree of bacterial enrichment, the dissected gill tissues of 10 haphazardly selected Loripes individuals were pooled, washed 3 times in sterile artificial seawater, and gently homogenized over ice in a Braun homogenizer. Differential centrifugation was used to remove animal cells and resulted in gill material highly enriched in bacterial tissue with respect to the original gill (for further details of the differential centrifugation protocol used, see Conway et al. 1989). This procedure was repeated for gills from the remaining 10 Loripes specimens. Microscopic examination of the 2 bacterial pellets indicated a large reduction in the presence of Loripes cell nuclei and other organelles. Both bacterial pellets were stored frozen $\left(-20^{\circ} \mathrm{C}\right)$ until further carbon isotopic analysis.

To investigate seasonal variability in heterotrophic feeding (i.e. SPOM feeding), we haphazardly selected a minimum of 3 Loripes specimens (measuring between 7 and $11 \mathrm{~mm}$ in shell height) from the monthly benthic samples taken at our study site between October 2009 and January 2011. From each Loripes the gills were dissected from remaining tissues (from the latter, the gonad-digestive gland complex was removed), and both gill and non-gill tissue samples were preserved in borax-buffered formalin $(4 \%)$.

Whereas freezing is generally considered to be the only method that does not affect $\delta^{13} \mathrm{C}$ values of marine organisms (Bosley \& Wainright 1999, Kaehler \& Pakhomov 2001), tissue fixation in formalin often results in significantly depleted $\delta^{13} \mathrm{C}$ values (reviewed in Barrow et al. 2008). To correct for possible effects of formalin on Loripes $\delta^{13} \mathrm{C}$ values, we did an explorative analysis. In October 2010, we sampled Loripes (ranging between 8 and $9 \mathrm{~mm}$ in shell length) of which we removed the somatic tissue, which was either stored frozen at $-20^{\circ} \mathrm{C}(\mathrm{n}=8)$ or stored in borax-buffered formalin $(4 \% ; n=3)$ for 9 mo. Subsequently, $\delta^{13} \mathrm{C}$ signatures of these somatic tissues were determined and a $t$-test was used to compare $\delta^{13} \mathrm{C}$ values between preservation treatments. This resulted in a significant difference between tissue preservation treatments $(t=3.83, \mathrm{df}=7.4, \mathrm{p}=0.006)$, with $\delta^{13} \mathrm{C}$ values in Loripes tissues preserved in formalin being $0.76 \%$ (95\% CI: 0.30 to 1.22 ) more depleted compared to those preserved frozen. We therefore corrected $\delta^{13} \mathrm{C}$ values for Loripes specimens that were preserved in formalin by adding $0.76 \%$ to the obtained $\delta^{13} \mathrm{C}$ values and used these corrected values for further analyses.

Loripes gill and non-gill tissue samples, SPOM, and the 2 bacterial pellets were freeze-dried for $72 \mathrm{~h}$, homogenized by mortar and pestle and analyzed for carbon stable isotope ratios. The $\delta^{13} \mathrm{C}$ values were obtained using a Thermo Scientific (Flash 2000) elemental analyzer coupled to a Delta V isotope mass spectrometer. The $\delta^{13} \mathrm{C}$ values for organic carbon are expressed per mille (\%o) deviation $(\delta)$ from the VPDB standard following the formula: $\delta^{13} \mathrm{C}$ $=\left[\left({ }^{13} \mathrm{C} /{ }^{12} \mathrm{C}\right)_{\text {sample }} /\left({ }^{13} \mathrm{C} /{ }^{12} \mathrm{C}\right)_{\text {standard }}-1\right] \times 1000$. The standard deviation for duplicate runs was $\pm 0.2 \%$. SPOM samples were treated with $2 \mathrm{M} \mathrm{HCl}$ to remove inorganic carbon $(2 \mathrm{M} \mathrm{HCl}$ was added, and kept for $12 \mathrm{~h}$ at $60^{\circ} \mathrm{C}$, after which samples were rinsed 3 times with demineralized water to remove $\mathrm{CaCl}_{2}$ and dried in an oven for $12 \mathrm{~h}$ at $60^{\circ} \mathrm{C}$ ). Explorative analysis showed that $\delta^{13} \mathrm{C}$ values of gill $(t=$ $-0.86, \mathrm{df}=14, \mathrm{p}=0.40$ ) and non-gill tissues of Loripes $(t=-1.62$, df $=14, \mathrm{p}=0.13$ ) were not significantly different after treatment of tissue samples with $2 \mathrm{M} \mathrm{HCl}$. Therefore, we refrained from treating the remaining Loripes tissue samples with $2 \mathrm{M} \mathrm{HCl}$ prior to stable carbon isotope analysis.

It was assumed that the lucinid host could derive carbon from 2 sources: the endosymbiotic bacteria or SPOM. For each month, the heterotrophic contribution to the carbon budget of Loripes was determined with a 2-source mixing model:

$$
\begin{aligned}
F= & 1-\left(\delta^{13} C_{\text {Loripes non-gill }}-\delta^{13} \mathrm{C}_{\mathrm{SPOM}}\right) / \\
& \left(\delta^{13} \mathrm{C}_{\text {bacterial pellet }}-\delta^{13} \mathrm{C}_{\mathrm{SPOM}}\right)
\end{aligned}
$$

where $F$ is the fractional heterotrophic contribution,

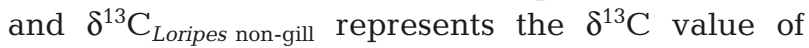
Loripes non-gill tissue corrected for the depletion 
effect of formalin. Carbon isotope values of the bacterial pellet were assumed to represent the endosymbiont $\delta^{13} \mathrm{C}$ values, while carbon isotope values of SPOM were taken to represent a SPOM-based food source. Following previous studies (Rossi et al. 2013), a trophic enrichment factor of $1 \%$ was used for the carbon isotope values of the bacterial pellet and SPOM.

\section{Statistical analysis}

We tested for seasonality by using a non-linear mixed-effect model with a sinusoidal effect $\beta_{0}+\beta_{1} \times$ Month + Season. Because explorative data analysis showed that there was a time trend in most of the parameters of interest (BMI, SMI, GMI and percentage of heterotrophic contribution), we accounted for a time trend in all models by including the term $\beta_{1} \times$ Month, where Month was a continuous variable that ran from 1 to 16 . Any seasonal variation was described as $\beta_{2} \times \sin \left[2 \pi \times\right.$ (Month $-\beta_{3}$ ) / $\left.\beta_{4}\right]$, where parameters $\beta_{2}, \beta_{3}$ and $\beta_{4}$ refer to the amplitude of seasonality, the timing of the peak and the frequency of peaks per year.

Our sample size was not sufficient to test for any significant differences in seasonal patterns in the BMI, SMI, GMI and gametogenic cycle between sexes; however, visual inspection of the data showed that these factors followed the same seasonal pattern in males and females, so data from both sexes were analyzed together to increase sample size. Using the full model, we tested for the frequency of peaks per year by setting $\beta_{4}$ to $3,4,6$ or 12 (respectively, $4,3,2$ or 1 peak(s) per year). GMI data were square-roottransformed to obtain normality while the percentage of gonads in spent stage and the percentage of heterotrophic contribution to the lucinid diet were logit-transformed (Warton \& Hui 2011). DM measurements of 2 Loripes specimens collected in February 2010 were lost during processing. Each month, at every sampling occasion, individuals were collected from 1 or 2 sediment cores collected within an area of $1 \mathrm{~m}^{2}$, and therefore these individuals cannot be treated as independent. To account for this pseudoreplication, we treated month as a random effect.

Model selection was based on Akaike's Information Criterion corrected for small sample sizes $\left(\mathrm{AIC}_{\mathrm{c} i}\right.$ Burnham \& Anderson 2002). $\triangle \mathrm{AIC}_{\mathrm{c}}$ values were used to compare the relative explanatory value of the models, with $\Delta \mathrm{AIC}_{\mathrm{c}}$ defined as the difference between the $\mathrm{AIC}_{\mathrm{c}}$ value of the best-fitting model and each respective model in the set. $\mathrm{AIC}_{\mathrm{c}}$ weights, which indicate the relative likelihood of a model given the data and set of models, were also calculated to provide a relative weight of evidence for each model (Burnham \& Anderson 2002). The effect of a parameter was considered significant when adding this parameter to the model reduced the $\mathrm{AIC}_{\mathrm{C}}$ by at least 2 points.

A Pearson correlation analysis was performed to evaluate the relationship between monthly mean values of environmental factors, feeding mode, and variables describing the body mass and reproductive cycle. Sediment temperature data were lacking for some months during our study period. Given the significant relationship between sediment temperature and air temperature $(t=5.29, \mathrm{df}=7, \mathrm{p}=0.001)$, we used air temperature together with precipitation as environmental factors in this analysis. Given the possibility that variables describing the reproductive cycle of Loripes (i.e. GMI and percentage of gonads in 'spent' stage) are not related to any particular threshold value but to an abrupt change in environmental conditions, we also explored their relationships with the change (i.e. increase or decrease) in air temperature and precipitation between sampling dates.

All analyses were performed in $\mathrm{R}$ version 3.0.0 (R Development Core Team 2013). For non-linear mixed-effect models, the R-package 'nlme' (Pinheiro et al. 2013) was used.

\section{RESULTS}

\section{Environmental variability}

The mean monthly sediment temperature showed a clear seasonal trend with a minimum in January $\left(19.5^{\circ} \mathrm{C}\right)$ and a maximum in September $\left(29.1^{\circ} \mathrm{C}\right.$; Fig. 2a). At Nouadhibou, the mean monthly air temperature paralleled mean monthly sediment temperatures at the study site, ranging from $20.6^{\circ} \mathrm{C}$ in January to $26.5^{\circ} \mathrm{C}$ in September. During the study period, total monthly precipitation $(\mathrm{mm})$ at Nouadhibou was mainly restricted to March, April and June with a small peak in September and October, while there was no rainfall in the 9 months preceding our study period (Fig. 2b).

\section{Body mass and reproduction}

A plot of the percentage of sexed animals against shell height (Fig. S1 in the Supplement) indicates that sexual differentiation for both males and females 


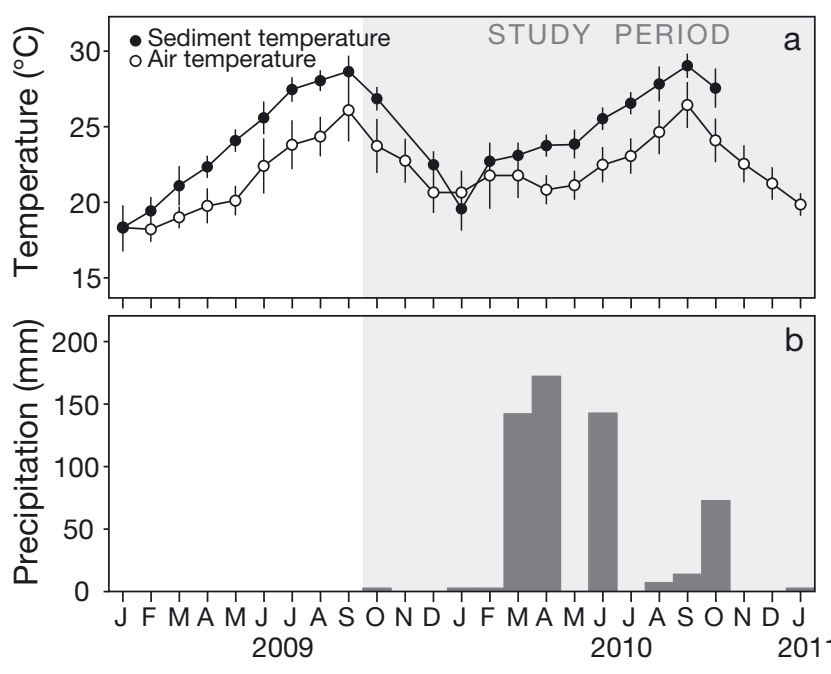

Fig. 2. Environmental conditions at Banc d'Arguin during our study period (grey shading) and in the 9 mo preceding our study period. (a) Mean monthly sediment temperature $(\bullet)$ and mean monthly air temperature $(0)$. Data are mean \pm SD. (b) Total monthly precipitation

started at a minimum shell height of $\sim 4 \mathrm{~mm}$. For individuals with a shell height $\geq 7 \mathrm{~mm}$, almost all specimens $(86 \%)$ could be sexed; therefore, we only used specimens $\geq 7 \mathrm{~mm}$ in shell height $(\mathrm{n}=203$ ind.) for further analyses.

Mean monthly BMI and SMI reached high values in late summer (i.e. July through September) and low values in winter (i.e. January through March) while both BMI and SMI increased slightly over time (Fig. 3a,b). For both BMI and SMI, the full model that fitted 1 peak yr${ }^{-1}\left(\beta_{4}=12\right)$ was best supported (Table 1). GMI also increased with time, but showed different seasonal patterns (Fig. 3c), with relatively high values in winter (December and January) and early summer (May to July) and relatively low values in early spring (February and March) and late summer (August and September). For GMI, the full model that fitted 2 peaks per year $\left(\beta_{4}=6\right)$ was best supported (Table 1). The fitted curve based on the optimal model prediction showed that GMI peaked in June and December, which corresponds to the months prior to spawning (Fig. 3c).

The distribution of gonadal stages over time shows that Loripes has a semi-annual gametogenic cycle, with high gametogenic activity between March and July, and again between September and February (Fig. 4). Two major spawning periods, indicated by increasing microscopic observation of 'spent' stages between January and February and between June

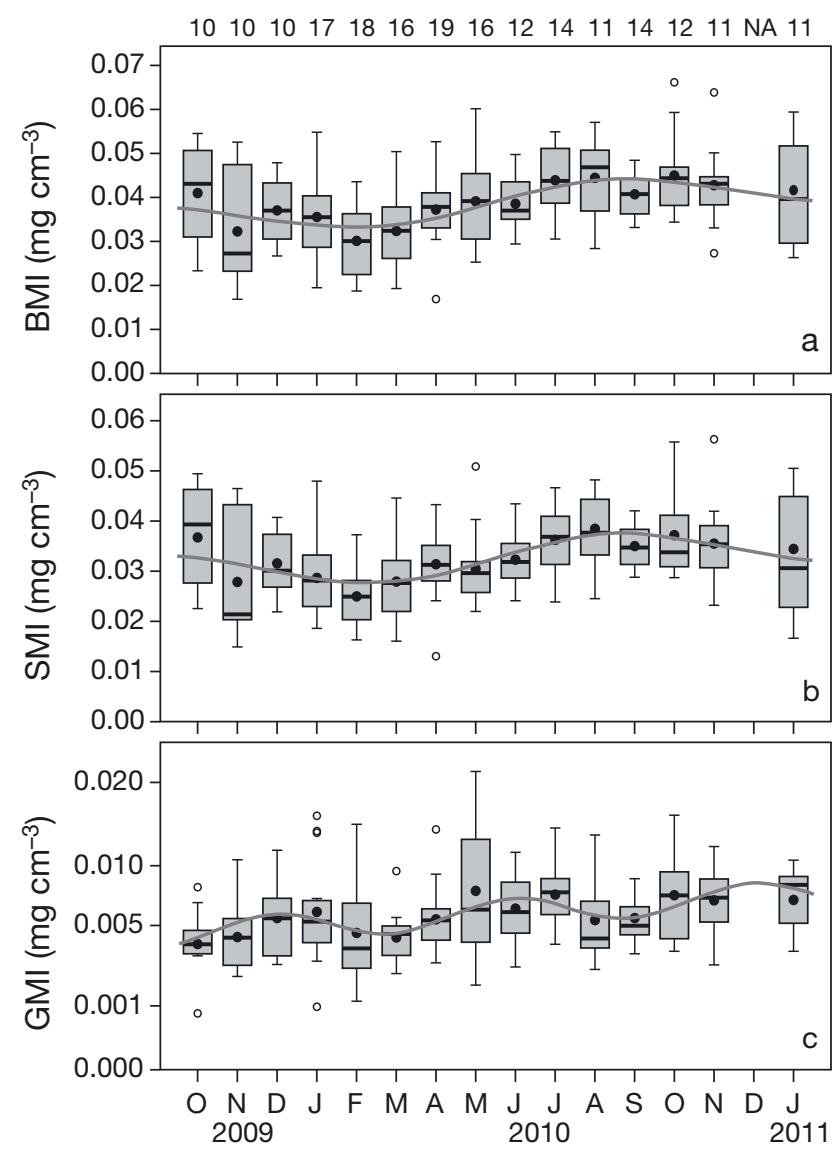

Fig. 3. Loripes lucinalis. (a) Body mass index (BMI), (b) somatic mass index (SMI), and (c) gonadal mass index (GMI) over time for $L$. lucinalis with shell height $\geq 7 \mathrm{~mm}$. Curves represent the best-supported model $\left(\beta_{0}+\beta_{1} \times\right.$ Month + Season) predictions. Box-and-whisker plots give the mean (filled dot), median (horizontal line inside the box), interquartile range (box), range (bars), and outliers (open circles). Numbers above box-and-whisker plots indicate sample sizes. NA: not available

and August, are evident (Fig. 4). For the percentage of gonads in 'spent' stage, the full model that fitted 2 peaks per year $\left(\beta_{4}=6\right)$ was indeed best supported (Table 1). The fitted curve based on this bestsupported model prediction showed that the percentage of gonads in 'spent' stage peaked in February and August, which corresponds to the months after spawning (Fig. 4). Combining results of GMI and percentage of gonads in 'spent' stage indicated 2 major spawning events: one in winter during January and February and a second one in summer during July and August.

Having determined the months in which the majority of the adult Loripes population is in the 'spent' stage (Fig. 4), we could use all examined individuals in these peak-breeding months (i.e. February and 
Table 1. Loripes lucinalis. Non-linear mixed-effect model results evaluating the best fit for $\beta_{4}$ for body, somatic and gonadal mass indices and percentage of heterotrophic contribution to the diet of $L$. lucinalis, and non-linear model results evaluating the best fit for $\beta_{4}$ for percentage of gonads in 'spent' stage. Season was described as the function $\beta_{2} \times \sin \left[2 \pi \times\left(\right.\right.$ Month $\left.\left.-\beta_{3}\right) / \beta_{4}\right]$. Models are listed in order of $\Delta \mathrm{AIC}_{\mathrm{c}}\left(\mathrm{AIC}_{\mathrm{c}}\right.$ : Akaike's Information Criterion corrected for small sample size). Bold: best-supported model

\begin{tabular}{|c|c|c|c|c|}
\hline & $\beta_{4}$ & $\begin{array}{l}\text { No. of model } \\
\text { parameters }\end{array}$ & $\Delta \mathrm{AIC}_{\mathrm{c}}$ & $\begin{array}{l}\text { Akaike } \\
\text { weight }\end{array}$ \\
\hline \multicolumn{5}{|l|}{ Body mass index } \\
\hline$\beta_{0}+\beta_{1} \times$ Month + Season & 12 & 6 & $0.00^{\mathrm{a}}$ & 0.97 \\
\hline$\beta_{0}+\beta_{1} \times$ Month & - & 4 & 7.83 & 0.02 \\
\hline$\beta_{0}+\beta_{1} \times$ Month + Season & 3 & 6 & 9.57 & 0.01 \\
\hline$\beta_{0}+\beta_{1} \times$ Month + Season & 6 & 6 & 10.64 & 0.00 \\
\hline$\beta_{0}+\beta_{1} \times$ Month + Season & 4 & 6 & 11.96 & 0.00 \\
\hline \multicolumn{5}{|l|}{ Somatic mass index } \\
\hline$\beta_{0}+\beta_{1} \times$ Month + Season & 12 & 6 & $0.00^{b}$ & 0.99 \\
\hline$\beta_{0}+\beta_{1} \times$ Month & - & 4 & 10.82 & 0.00 \\
\hline$\beta_{0}+\beta_{1} \times$ Month + Season & 3 & 6 & 13.04 & 0.00 \\
\hline$\beta_{0}+\beta_{1} \times$ Month + Season & 6 & 6 & 14.37 & 0.00 \\
\hline$\beta_{0}+\beta_{1} \times$ Month + Season & 4 & 6 & 14.78 & 0.00 \\
\hline \multicolumn{5}{|c|}{ Gonadal mass index (square-root-transformed) } \\
\hline$\beta_{0}+\beta_{1} \times$ Month + Season & 6 & 6 & $0.00^{\mathrm{c}}$ & 0.87 \\
\hline$\beta_{0}+\beta_{1} \times$ Month & - & 4 & 4.76 & 0.08 \\
\hline$\beta_{0}+\beta_{1} \times$ Month + Season & 3 & 6 & 7.34 & 0.02 \\
\hline$\beta_{0}+\beta_{1} \times$ Month + Season & 4 & 6 & 8.13 & 0.01 \\
\hline$\beta_{0}+\beta_{1} \times$ Month + Season & 12 & 6 & 8.14 & 0.01 \\
\hline \multicolumn{5}{|c|}{ Heterotrophic contribution (logit-transformed) } \\
\hline$\beta_{0}+\beta_{1} \times$ Month + Season & 12 & 6 & $\mathbf{0 . 0 0 ^ { \mathrm { d } }}$ & 1.00 \\
\hline$\beta_{0}+\beta_{1} \times$ Month & - & 4 & 11.62 & 0.00 \\
\hline$\beta_{0}+\beta_{1} \times$ Month + Season & 3 & 6 & 14.67 & 0.00 \\
\hline$\beta_{0}+\beta_{1} \times$ Month + Season & 6 & 6 & 16.12 & 0.00 \\
\hline$\beta_{0}+\beta_{1} \times$ Month + Season & 4 & 6 & 16.21 & 0.00 \\
\hline \multicolumn{5}{|c|}{ Percentage spent (logit-transformed) } \\
\hline$\beta_{0}+\beta_{1} \times$ Month + Season & 6 & 5 & $0.00^{\mathrm{e}}$ & 0.99 \\
\hline$\beta_{0}+\beta_{1} \times$ Month & - & 3 & 9.94 & 0.01 \\
\hline$\beta_{0}+\beta_{1} \times$ Month + Season & 12 & 5 & 15.78 & 0.00 \\
\hline$\beta_{0}+\beta_{1} \times$ Month + Season & 4 & 5 & 17.27 & 0.00 \\
\hline$\beta_{0}+\beta_{1} \times$ Month + Season & 3 & 5 & 17.60 & 0.00 \\
\hline \multicolumn{5}{|c|}{$\begin{array}{l}{ }^{\mathrm{a}} \mathrm{AIC}_{\mathrm{C}}=-1316.78 ;{ }^{\mathrm{b}} \mathrm{AIC}_{\mathrm{c}}=-1361.95 ;{ }^{\mathrm{c}} \mathrm{AIC}_{\mathrm{c}}=-1007.93 ;{ }^{\mathrm{d}} \mathrm{AIC}_{\mathrm{C}}=-21.93 ; \\
\mathrm{e}^{\mathrm{AIC}} \mathrm{C}_{\mathrm{C}}=39.56\end{array}$} \\
\hline
\end{tabular}

$(+0.76 \%)$ for $\delta^{13} \mathrm{C}$ values of gill and non-gill tissues to account for the depletion effect of formalin). There was a significant relationship between gill $\delta^{13} \mathrm{C}$ values and $\delta^{13} \mathrm{C}$ values of non-gill tissue $\left(y=-7.52+0.65 x_{;} F_{1,46}=100.5\right.$, $\mathrm{p}<0.001)$, with $\delta^{13} \mathrm{C}$ values of gill tissue being on average $1.0 \pm 0.4 \%$ (mean \pm $\mathrm{SD}$ ) more depleted. The average mean monthly $\delta^{13} \mathrm{C}$ value of gill tissue was $-24.7 \pm 0.58 \%$, whereas the average mean monthly $\delta^{13} \mathrm{C}$ value of non-gill tissue was $-23.7 \pm 0.5 \%$.

Relatively low $\delta^{13} \mathrm{C}$ values for the non-gill tissues were observed in November 2009 and from February to June 2010 (Fig. 5). The $\delta^{13} \mathrm{C}$ values for the bacterial pellets were $-27.2 \pm 0.2 \%$ o ( $\mathrm{n}=2$ ), while the $\delta^{13} \mathrm{C}$ values for SPOM were $-18.7 \pm 1.2 \%$ o $(\mathrm{n}=2)$. Using the mean $\delta^{13} \mathrm{C}$ values for the bacterial pellets and SPOM, results from the 2source mixing model show that on average, $29 \%$ of the carbon nutrition is obtained by feeding on SPOM, with a minimum mean monthly heterotrophic contribution observed in March (21\%) and a maximum mean monthly heterotrophic contribution observed in September $(39 \%)$. The full model that fitted one peak per year $\left(\beta_{4}=12\right)$ was best supported (Table 1, Fig. 5).

\section{Factors affecting nutrition and resource allocation}

The Pearson correlation analysis showed significant correlations be-

July) to investigate the size at first reproduction. (i.e. the smallest size-class where percentage of gonads in 'spent' stage is higher than 50\%) in the Loripes population. This resulted in a size at first reproduction of $\sim 7.5 \mathrm{~mm}$ in shell height (see Fig. S2 in the Supplement).

\section{Stable isotopes}

The $\delta^{13} \mathrm{C}$ values of both gill and non-gill tissues of Loripes collected between October 2009 and January 2011 were compared to determine isotopic differences (note that we have used the correction factor tween nutrition and environmental and biological variables (see Fig. S3 in the Supplement): a positive correlation existed between the logit-transformed percentage of heterotrophic contribution to the diet of Loripes and both BMI ( $\mathrm{r}=0.766, \mathrm{p}<0.001)$ and SMI ( $\mathrm{r}=0.787, \mathrm{p}<0.001)$, SMI and air temperature $(\mathrm{r}=0.541, \mathrm{p}=0.04), \mathrm{BMI}$ and SMI $(\mathrm{r}=0.962, \mathrm{p}<$ 0.001), and between BMI and GMI ( $r=0.620, p=$ 0.01). In addition, the change in mean monthly air temperature was positively correlated with the logittransformed percentage of gonads in spent stage $(\mathrm{r}=$ 0.640, $\mathrm{p}=0.01$ ), while the change in total monthly precipitation was positively correlated with total monthly precipitation $(\mathrm{r}=0.665, \mathrm{p}=0.01)$. 


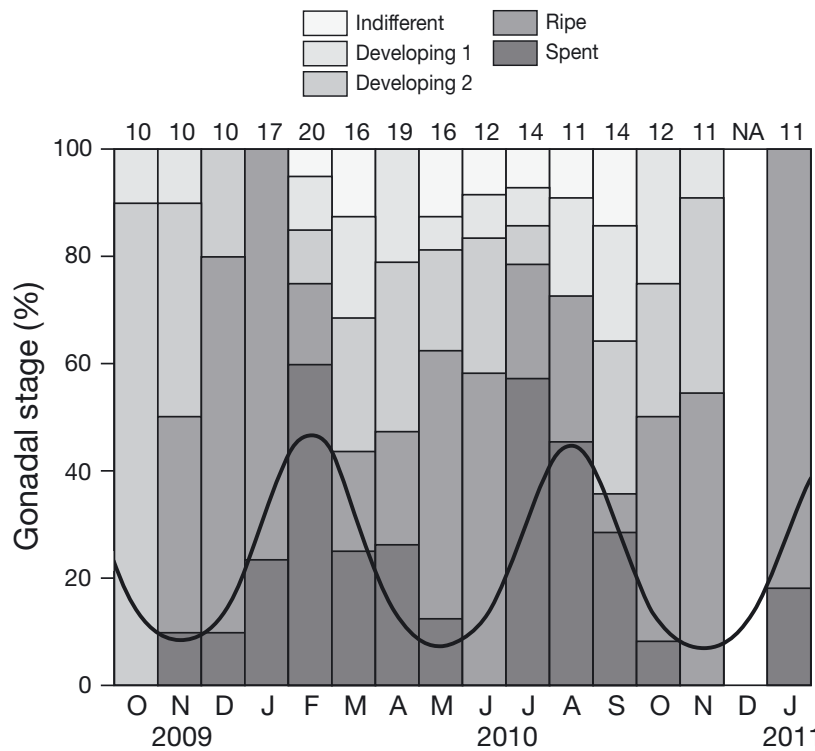

Fig. 4. Loripes lucinalis. Gametogenic cycle of L. lucinalis based on gonadal stages from microscopic observations of smear samples of individuals $\geq 7 \mathrm{~mm}$ in shell height. Curve represents the best-supported model $\left(\beta_{0}+\beta_{1} \times\right.$ Month + Season) predictions. Numbers above columns indicate sample sizes. NA: not available

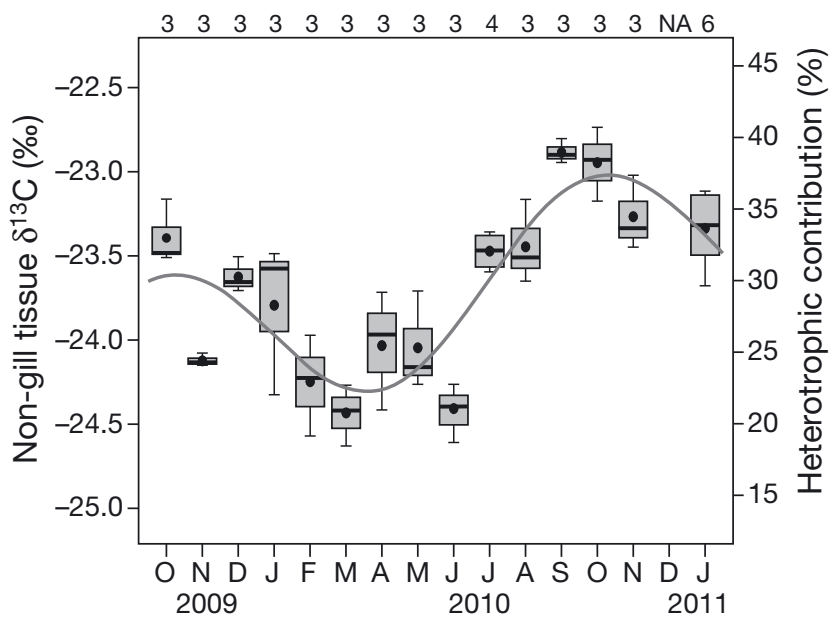

Fig. 5. Loripes lucinalis. $\delta^{13} \mathrm{C}$ values over time for non-gill tissues of mature L. lucinalis (enriched by $0.76 \%$ to correct for the depletion effect of formalin [4\%] in which the tissues were preserved), as well as the percentage of the heterotrophic contribution to the carbon diet of mature $L$. lucinalis. Curve represents the best-supported model $\left(\beta_{0}+\beta_{1} \times\right.$ Month + Season) predictions. Box-and-whisker plots give the mean (black dot), median (horizontal line inside the box), interquartile range (box), and range (bars). Numbers above boxand-whisker plots indicate sample sizes. NA: not available

\section{DISCUSSION}

Results from the 2-source mixing model indicated that Loripes has a mixotrophic carbon diet, with an important contribution of its bacterial chemosym- bionts to its carbon nutrition, but also a substantial contribution of SPOM (on average 71 and $29 \%$, respectively; Fig. 5). This is consistent with the findings of Rossi et al. (2013) that SPOM-derived carbon nutrition in Loripes inhabiting a Mediterranean Zostera noltii seagrass bed amounts to $\sim 75 \%$.

Our study also identified strong seasonality in feeding modes in tropical Loripes (see Fig. 5), with the maximum heterotrophic contribution in September $(39 \%)$ being nearly 2 -fold the heterotrophic contribution observed in March (21\%). If SPOM-derived food is of higher nutritional value than carbon metabolites provided by sulphide-oxidizing endosymbionts, and if SPOM is in short supply, then optimal foraging theory predicts that body condition (i.e. BMI) would be positively correlated with the degree of heterotrophic-feeding, as indeed was the case in our study (Fig. S3 in the Supplement).

If SPOM-derived food is preferred by Loripes, then optimal foraging theory also predicts that the heterotrophic contribution to the diet of Loripes would be positively correlated with SPOM availability. The switch to more heterotrophic feeding in autumn would then suggest increased SPOM availability in autumn. This corroborates Lavaud et al. (2013), who found that growth rates of suspension-feeding Senilia senilis, a common bivalve at Banc d'Arguin, peaked in August and September. If true, the observed positive time trend in BMI, SMI, GMI (Fig. 3) and heterotrophic feeding (Fig. 5) may be the direct result of a positive time trend in SPOM availability.

However, an alternative mechanism may also explain why heterotrophic feeding in Loripes was more predominant in the warm autumn months (i.e. August through October, Fig. 2a). In marine sediments, sulphide is mainly produced by anaerobic decomposition of organic matter by sulphate-reducing bacteria (Jørgensen 1982). The metabolic rate of these sulphate-reducing bacteria is regulated by temperature, resulting in higher bacterial sulphate reduction activity levels when temperatures rise (Jørgensen 1977). Indeed, sediment sulphide concentration measured at the 8 to $12 \mathrm{~cm}$ sediment layer at our study site followed seasonal changes in temperature, with relatively low sulphide concentrations measured in the coldest month of the year (January 2011), reaching $119 \pm 69\left(\right.$ mean \pm SE) $\mu \mathrm{mol} \mathrm{l}^{-1}$ (L. L. Govers and J. de Fouw unpubl. data), and relatively high sulphide concentrations reaching almost $300 \mu_{\mathrm{mol}}{ }^{-1}$ in one of the warmest months of the year (October 2010) (van Gils et al. 2012). When in contact with oxygen, sulphide is immediately oxidized back to sulphate via intermediate oxidation steps, partly by a spon- 
taneous chemical reaction, and partly by catalysis by chemoautotrophic or phototrophic sulphide-oxidizing bacteria (Jørgensen 1977). This results in an inverse relationship between sediment sulphide levels and sediment oxygen levels (Lee \& Dunton 2000). The relatively high pore water sulphide concentrations in October thus reflect anaerobic sediment conditions. Moreover, the positive correlation between temperature and sediment sulphate reducing rates also implies a negative correlation between temperature and sediment oxygen levels. This suggests that low pore water oxygen levels during the relatively warm autumn months may limit carbon metabolite production by the sulphide-oxidizing gill-bacteria of Loripes during this period, for which the lucinid host tries to compensate by supplementary heterotrophic feeding (note that this would imply that carbon metabolites provided by the gill-symbionts are preferred over SPOM). Such a mechanism would be in agreement with Childress \& Girguis (2011), who showed that chemosymbiotic bivalves have much higher oxygen demands than non-chemosymbiotic bivalves, which implies that the high oxygen demand of chemosymbiotic bacteria is the most limiting flux for the symbiosis. Moreover, if temperature-dependent sediment oxygen levels are determining the rate of carbon fixation by the sulphide-oxidizing gill-bacteria, one would predict a negative correlation between temperature and the bacterial contribution to the diet of Loripes - which indeed was found, although not statistically significant (Pearson's $r=0.501, \mathrm{p}=0.06$; Fig. S3). Overall, high SPOM availability or oxygenlimited carbon metabolite production by sulphideoxidizing endosymbionts may explain why Loripes showed a diet shift to more heterotrophic feeding from June to October (Fig. 5).

Although the Supplementary incorporation of SPOM to the diet of Loripes may have contributed to its survival, the drop in BMI from October onwards (Fig. 3a) indicates that supplemental nutrition obtained from heterotrophic feeding was insufficient for body mass maintenance over winter. As suggested by van Gils et al. (2012), competition for SPOM with more specialized suspension-feeding bivalves, which are especially abundant between September and November (Ahmedou Salem et al. 2014), may have limited heterotrophic feeding in Loripes.

Our study also identified strong reproductive periodicity in Loripes, with gametogenesis being initiated in both March and September, resulting in major spawning events during January and February, and again in June through August (Fig. 4). This is supported by the model that fitted 2 peaks per year $\left(\beta_{4}=6\right)$ being best supported for GMI and percentage of gonads in 'spent' stage (Table 1). The latter suggests that some individuals may have spawned in June. However, in view of the observation that GMI increased from June to July, and that the minimum GMI values in July were still relatively high (indicating that spawning had only just commenced), we suggest that this second spawning event was mainly restricted to July.

Gametogenesis and spawning is generally considered to be triggered proximately by environmental cues (Sastry 1979). In this study, we found a positive correlation between the monthly change in mean air temperature and the percentage of gonads in 'spent' stage (Fig. S3), suggesting that increased temperature may have triggered spawning in tropical Loripes. This contrasts with the findings of Johnson \& Le Pennec (1994) for a temperate Loripes population for which environmental triggers of spawning were not readily apparent. The lack of a correlation between heterotrophic feeding and reproductive activity (Fig. S3) suggests that SPOM availability does not affect the reproductive cycle in tropical Loripes. However, the observed gonadal and gametogenic development between September and January (Figs. 3c \& 4, respectively) when food availability seems to decrease (as reflected by a decrease in $\mathrm{BMI}$ ), does seem to require supplemental nutrition by heterotrophic feeding (Fig. 5). That we predicted size at first reproduction to be reached at $\sim 7.5 \mathrm{~mm}$ shell height, suggests that the choice to only include Loripes with shell heights $\geq 7 \mathrm{~mm}$ to identify its reproductive biology is justified.

In marine invertebrates, as in other animals, food is the most important factor controlling growth (Clarke 1987). If we assume that seasonality in body mass represents variability in food availability, the increase in BMI from February to October would suggest ample food availability, while the drop in BMI observed between October and February might reflect food limitation during this period (Fig. 3a). Given that GMI and the percentage of gonads in 'ripe' stage increased from September to January (Figs. 3c \& 4, respectively), this decrease in BMI from October to February is mainly the result of SMI decreasing in this period (Fig. 3b). This would suggest that in winter, reproduction is based on stored resources ('capital' already invested in the soma), which is referred to as 'capital breeding' (Stearns 1992, Jønsson 1997). By producing offspring from stored resources, capital breeders decouple feeding and reproduction in contrast to reproduction based on concurrent food intake, which is termed 'income breeding' (Stearns 1992, Jønsson 1997). This strategy would enable 
Loripes to reproduce in January at the onset of the next feeding season, thereby presumably increasing offspring fitness. However, given the cost of carrying stores and the finite risk of mortality between resource acquisition and deployment to reproduction (Jønsson 1997), good feeding conditions between February and October may explain why Loripes adopted an income breeding strategy during this period. An intriguing question to ask may be whether the individuals reproduce once or twice per year, and if once, which individuals reproduce when? Given that only about $60 \%$ of all individuals were in 'spent' stage during the major spawning events in January and February, and in July and August, we may argue that on an individual basis, reproduction is limited to once per year only. If true, it would be very interesting to study the forces that may determine timing of reproduction at an individual basis.

The clear seasonality in the $\delta^{13} \mathrm{C}$ values of non-gill tissues of Loripes observed in this study (Fig. 5) may not solely be the result of a diet shift. Among the factors that could have caused such seasonality in organic composition, sediment temperature may be one of them, since experimental studies showed carbon isotopic enrichment with increasing temperature (Sackett et al. 1965, Power et al. 2003). However, sediment temperature increased from January to September, while $\delta^{13} \mathrm{C}$ values of Loripes only started to become more enriched by July, which suggests that local temperature cannot explain the observed seasonality in $\delta^{13} \mathrm{C}$ values of Loripes non-gill tissues. Although not statistically significant, we did find some support for a positive correlation between air temperature and heterotrophic feeding (Fig. S3); but as explained above, this correlation could be the result of temperature-dependent oxygen availability determining the bacterial contribution to the carbon diet of Loripes. Altogether, it remains difficult to assess whether increasing temperature by itself caused $\delta^{13} \mathrm{C}$ values of Loripes to be more enriched in the warmer autumn months, or if an increase in heterotrophic feeding in this period caused more enriched $\delta^{13} \mathrm{C}$ values in Loripes.

Lipids have a more depleted $\delta^{13} \mathrm{C}$ signature than proteins (DeNiro \& Epstein 1977). Temporal variability in tissue lipid content, which often varies with degree of reproductive activity (Berthelin et al. 2000, Ojea et al. 2004), may have affected the $\delta^{13} \mathrm{C}$ signatures of non-gill tissues of Loripes and, in addition, could have resulted in erroneous estimates of the heterotrophic contribution to the carbon diet of Loripes. If this is the case, one would expect the lipid content of Loripes tissues to be more depleted in periods of starvation (the end of winter, i.e. January through March) and subsequent $\delta^{13} \mathrm{C}$ values of Loripes tissues to be more enriched in such periods. However, in our study, $\delta^{13} \mathrm{C}$ values of Loripes become more depleted in periods of starvation (between September and March; Fig. 5), suggesting that the lipid effect on tissue $\delta^{13} \mathrm{C}$ values is either very limited or that the predicted seasonality in heterotrophic contribution is too conservative.

A weakness of this study is our assumption that $\delta^{13} \mathrm{C}$ values of bacterial endosymbionts and SPOM are constant over time. To our knowledge, there are no studies that have investigated whether $\delta^{13} \mathrm{C}$ values of chemosymbiotic bacterial endosymbionts vary seasonally. However, when investigating seasonal differences in $\delta^{13} \mathrm{C}$ values of SPOM in a temperate intertidal Zostera noltii bed, Lebreton et al. (2012) found $\delta^{13} \mathrm{C}$ values to range between $-21.4 \%$ in autumn and $-23.5 \%$ in spring, with a yearly average $( \pm$ SD) over all 4 seasons of $-22.5 \%$ o $( \pm 0.9)$. Likewise, our $\delta^{13} \mathrm{C}$ values of Loripes were most depleted in spring (Fig. 5), which suggests that the observed seasonality in heterotrophic diet could be the result of seasonal variability in $\delta^{13} \mathrm{C}$ values of SPOM, but only to some extent. If we assume that the $\delta^{13} \mathrm{C}$ value of SPOM at Banc d'Arguin varies to a similar extent, thus from $-18.7 \%$ in spring (see 'Results: Stable isotopes') to $-16.6 \%$ in autumn, then the estimated seasonality in heterotrophic contribution would be reduced from $22-38 \%$ to $22-30 \%$. However, until further research shows otherwise, we assume that the observed seasonality in $\delta^{13} \mathrm{C}$ values of Loripes tissues reflects seasonality in heterotrophic feeding.

Lucinid bivalves often dominate the infauna of sulphide-rich anoxic sediments of tropical seagrass beds, which is attributed to a 3-stage symbiosis between seagrass, lucinid bivalves and their sulphideoxidizing bacteria (van der Heide et al. 2012). In this 3-stage symbiosis, the bivalve-sulphide-oxidizer symbiosis reduces sulphide levels, which enhances seagrass production. In turn, seagrass meadows provide an optimal habitat for lucinid bivalves and their symbionts by indirectly stimulating sulphide production through high organic matter input and by providing oxygen through radial oxygen release from their roots (van der Heide et al. 2012). However, this study shows that the ability of lucinid bivalves to also feed on SPOM plays a key role in influencing resource allocation strategies and the synchronization and timing of reproduction, which will have important fitness consequences in terms of reproductive output, mating efficiency and offspring fitness and subsequent population dynamics. 
Although the precise mechanism remains unsolved, this study also reveals strong seasonality in diet composition, with the heterotrophic contribution to the carbon diet of Loripes increasing from June to October (Fig. 5). At a short time scale, the diet shift towards more heterotrophic feeding in autumn implies reduced sulphide uptake by the gill-symbionts of Loripes, which may result in increased pore water sulphide levels in autumn, as was indeed observed (van Gils et al. 2012). Because sulphide is toxic to plants (reviewed in Lamers et al. 2013), increased pore water sulphide levels in autumn may promote 'die-off' events of Zostera noltii at Banc d'Arguin in this period, as has been proposed for many seagrass species worldwide (Holmer \& Bondgaard 2001, Borum et al. 2006, Calleja et al. 2007). The more so, because during the relatively warm autumn at Banc d'Arguin, Z. noltii, which has its most southern distribution at Banc d'Arguin (Short et al. 2007), may already experience high thermal stress (Koch et al. 2007, Massa et al. 2009).

However, at a larger time scale, the diet shift towards more heterotrophic feeding in autumn may be beneficial for the Zostera noltii beds at Banc d'Arguin, since it will increase growth, reproduction and survival in Loripes in this season, resulting in a larger population of Loripes that is better capable of controlling pore water sulphide levels, thus enhancing seagrass production and prevalence (van der Heide et al. 2012). Since seagrass ecosystems are currently declining at increasing rates worldwide, leading to loss of biodiversity (Waycott et al. 2009), we believe that knowledge about the biological and environmental processes that regulate feeding behaviour and population dynamics in chemosymbiotic lucinid bivalves as presented in this study, will aid seagrass management and conservation.

Acknowledgements. We are grateful to the Parc National du Banc d'Arguin (PNBA) for their permission to work in the park and for the use of their facilities. The PNBA crew at Iwik, and Lemhaba Ould Yarba at PNBA headquarters in Nouakchott are thanked for logistical support. We thank D. Rekers, M. Kienhuis and J. Ossebaar for help with stable isotope analyses. We are also indebted to A. Noordeloos and D. Maat for their help in isolating endosymbiotic bacteria from lucinid gill tissues. We are grateful for the constructive feedback from 3 anonymous reviewers. D. Visser polished the figures. This work was primarily funded by the NWOWOTRO Integrated Programme grant W.01.65.221.00 to T.P., but also by the NWO-VIDI grant 864.09.002 to J.A.v.G.

\section{LITERATURE CITED}

- Ahmedou Salem MV, van der Geest M, Piersma T, Saoud Y, van Gils JA (2014) Seasonal changes in mollusc abun- dance in a tropical intertidal ecosystem, Banc d'Arguin (Mauritania): testing the 'shorebird depletion' hypothesis. Estuar Coast Shelf Sci 136:26-34

Altenburg W, Engelmoer M, Mes R, Piersma T (1982) Wintering waders on the Banc d'Arguin, Mauritania. Report of the Netherlands ornithological expedition 1980. Stichting Veth tot Steun aan Waddenonderzoek, Leiden

Barrow LM, Bjorndal KA, Reich KJ (2008) Effects of preservation method on stable carbon and nitrogen isotope values. Physiol Biochem Zool 81:688-693

Berthelin C, Kellner K, Mathieu M (2000) Storage metabolism in the Pacific oyster (Crassostrea gigas) in relation to summer mortalities and reproductive cycle (West Coast of France). Comp Biochem Physiol B Biochem Mol Biol 125:359-369

Borum J, Sand-Jensen K, Binzer T, Pedersen O, Greve TM (2006) Oxygen movement in seagrasses. In: Larkum A, Orth R, Duarte C (eds) Seagrasses: biology, ecology and conservation. Springer, Dordrecht

Bosley KL, Wainright SC (1999) Effects of preservatives and acidification on the stable isotope ratios $\left({ }^{15} \mathrm{~N}:{ }^{14} \mathrm{~N},{ }^{13} \mathrm{C}:{ }^{12} \mathrm{C}\right)$ of two species of marine animals. Can J Fish Aquat Sci 56:2181-2185

Burnham KP, Anderson DR (2002) Model selection and multimodel inference: a practical information-theoretic approach. Springer-Verlag, New York, NY

Calleja ML, Marba N, Duarte CM (2007) The relationship between seagrass (Posidonia oceanica) decline and sulfide porewater concentration in carbonate sediments. Estuar Coast Shelf Sci 73:583-588

Cary SC, Vetter RD, Felbeck H (1989) Habitat characterization and nutritional strategies of the endosymbiontbearing bivalve Lucinoma aequizonata. Mar Ecol Prog Ser 55:31-45

Cavanaugh CM (1983) Symbiotic chemoautotrophic bacteria in marine invertebrates from sulfide-rich habitats. Nature 302:58-61

Childress JJ, Girguis PR (2011) The metabolic demands of endosymbiotic chemoautotrophic metabolism on host physiological capacities. J Exp Biol 214:312-325

Clarke A (1987) Temperature, latitude and reproductive effort. Mar Ecol Prog Ser 38:89-99

- Conway N, Capuzzo JM, Fry B (1989) The role of endosymbiotic bacteria in the nutrition of Solemya velum: evidence from a stable isotope analysis of endosymbionts and host. Limnol Oceanogr 34:249-255

Crosby MP, Gale LD (1990) A review and evaluation of bivalve condition index methodologies with a suggested standard method. J Shellfish Res 9:233-238

> Dando PR, Spiro B (1993) Varying nutritional dependence of the thysarid bivalves Thyasira sarsi and T. equalis on chemautotrophic symbiotic bacteria, demonstrated by isotope ratios of tissue carbon and shell carbonate. Mar Ecol Prog Ser 92:151-158

DeNiro MJ, Epstein S (1977) Mechanism of carbon isotope fractionation associated with lipid-synthesis. Science 197:261-263

> Dixon DR, Lowe DM, Miller PI, Villemin GR and others (2006) Evidence of seasonal reproduction in the Atlantic vent mussel Bathymodiolus azoricus, and an apparent link with the timing of photosynthetic primary production. J Mar Biol Assoc UK 86:1363-1371

$>$ Dufour SC, Felbeck H (2006) Symbiont abundance in thyasirids (Bivalvia) is related to particulate food and sulphide availability. Mar Ecol Prog Ser 320:185-194 
Duplessis MR, Dufour SC, Blankenship LE, Felbeck H, Yayanos AA (2004) Anatomical and experimental evidence for particulate feeding in Lucinoma aequizonata and Parvilucina tenuisculpta (Bivalvia: Lucinidae) from the Santa Barbara Basin. Mar Biol 145:551-561

Felbeck H, Childress JJ, Somero GN (1981) Calvin-Benson cycle and sulfide oxidation enzymes in animals from sulfide-rich habitats. Nature 293:291-293

Fisher MR, Hand SC (1984) Chemoautotrophic symbionts in the bivalve Lucina floridana from seagrass beds. Biol Bull 167:445-459

Fournier ML (1992) The reproductive biology of the tropical rocky oyster Ostrea iridescens (Bivalvia, Ostreidae) on the Pacific coast of Costa Rica. Aquaculture 101: 371-378

Fry B (2006) Stable isotope ecology. Springer, New York, NY

> Grant A, Tyler PA (1983) The analysis of data in studies of invertebrate reproduction. I. Introduction and statistical analysis of gonad indexes and maturity indexes. Int $\mathrm{J}$ Invertebr Reprod 6:259-269

Guillou J, Bachelet G, Desprez M, Ducrotoy JP and others (1990) Les modalités de la reproduction de la coque (Cerastoderma edule) sur le littoral français de la Manche et de l'Atlantique. Aquat Living Resour 3:29-42

> Holmer M, Bondgaard EJ (2001) Photosynthetic and growth response of eelgrass to low oxygen and high sulfide concentrations during hypoxic events. Aquat Bot 70:29-38

> Honkoop PJC, Beukema JJ (1997) Loss of body mass in winter in three intertidal bivalve species: an experimental and observational study of the interacting effects between water temperature, feeding time and feeding behaviour. J Exp Mar Biol Ecol 212:277-297

> Jager Z (1993) The distribution and abundance of young fish in the Banc d'Arguin, Mauritania. Hydrobiologia 258: 185-196

> Johnson MA, Le Pennec M (1994) The development of the female gamete in the endosymbiont-bearing bivalve Loripes lucinalis. J Mar Biol Assoc UK 74:233-242

Johnson M, Diouris M, Le Pennec M (1994) Endosymbiotic bacterial contribution in the carbon nutrition of Loripes lucinalis (Mollusca: Bivalvia). Symbiosis 17:1-13

> Johnson MA, Paulet YM, Donval A, Le Pennec M (1996) Histology, histochemistry and enzyme biochemistry in the digestive system of the endosymbiont-bearing bivalve Loripes lucinalis (Lamarck). J Exp Mar Biol Ecol 197: 15-38

> Jønsson KI (1997) Capital and income breeding as alternative tactics of resource use in reproduction. Oikos 78 : $57-66$

> Jørgensen BB (1977) Sulfur cycle of a coastal marine sediment (Limfjorden, Denmark). Limnol Oceanogr 22: 814-832

Jørgensen BB (1982) Mineralisation of organic matter in the sea bed: the role of sulphate reduction. Nature 296: 643-645

> Kaehler S, Pakhomov EA (2001) Effects of storage and preservation on the $\delta^{13} \mathrm{C}$ and $\delta^{15} \mathrm{~N}$ signatures of selected marine organisms. Mar Ecol Prog Ser 219:299-304

Koch MS, Schopmeyer S, Kyhn-Hansen C, Madden CJ (2007) Synergistic effects of high temperature and sulfide on tropical seagrass. J Exp Mar Biol Ecol 341:91-101

Lamers LPM, Govers LL, Janssen ICJM, Geurts JJM and others (2013) Sulfide as a soil phytotoxin - a review. Front Plant Sci 4:268

> Lavaud R, Thébault J, Lorrain A, van der Geest M, Chau- vaud L (2013) Senilia senilis (Linnaeus, 1758), a biogenic archive of environmental conditions on the Banc d'Arguin (Mauritania). J Sea Res 76:61-72

Lee KS, Dunton KH (2000) Diurnal changes in pore water sulfide concentrations in the seagrass Thalassia testudinum beds: the effects of seagrasses on sulfide dynamics. J Exp Mar Biol Ecol 255:201-214

- Le Pennec M, Beninger PG (2000) Reproductive characteristics and strategies of reducing-system bivalves. Comp Biochem Physiol A 126:1-16

Le Pennec M, Herry A, Diouris M, Moraga D, Donval A (1988) Chimioautotrophie et nutrition chez les Lucinacea, bivalves littoraux de milieux réducteurs. II. Charactéristiques morphologique des bactéries symbiotiques et modifications structurales adaptatives des branchies de l'hôte. Haliotis 18:207-217

Le Pennec M, Herry A, Johnson M, Beninger P (1995) Nutrition-gametogenesis relationship in the endosymbiont host-bivalve Loripes lucinalis (Lucinidae) from reducing coastal habitats. In: Eleftheriou A, Ansell AD, Smith CJ (eds) Biology and ecology of shallow coastal waters. Olsen \& Olsen, Fredensborg

> Lebreton B, Richard P, Galois R, Radenac G and others (2012) Food sources used by sediment meiofauna in an intertidal Zostera noltii seagrass bed: a seasonal stable isotope study. Mar Biol 159:1537-1550

> MacDonald BA, Thompson RJ (1986) Influence of temperature and food availability on the ecological energetics of the giant scallop Placopecten magellanicus. III. Physiological ecology, the gametogenic cycle and scope for growth. Mar Biol 93:37-48

> Massa SI, Arnaud-Haond S, Pearson GA, Serrao EA (2009) Temperature tolerance and survival of intertidal populations of the seagrass Zostera noltii (Hornemann) in southern Europe (Ria Formosa, Portugal). Hydrobiologia 619: 195-201

Ojea J, Pazos AJ, Martinez D, Novoa S, Sanchez JL, Abad M (2004) Seasonal variation in weight and biochemical composition of the tissues of Ruditapes decussatus in relation to the gametogenic cycle. Aquaculture 238: 451-468

Peterson BJ, Fry B (1987) Stable isotopes in ecosystem studies. Annu Rev Ecol Syst 18:293-320

Pile AJ, Young CM (1999) Plankton availability and retention efficiencies of cold-seep symbiotic mussels. Limnol Oceanogr 44:1833-1839

Pinheiro JC, Bates DM, DebRoy S, Sarkar D (2013) nlme: linear and nonlinear mixed effects models. R package version 31-109

> Pouvreau S, Gangnery A, Tiapari J, Lagarde F, Garnier M, Bodoy A (2000) Gametogenic cycle and reproductive effort of the tropical blacklip pearl oyster, Pinctada margaritifera (Bivalvia: Pteriidae), cultivated in Takapoto atoll (French Polynesia). Aquat Living Resour 13:37-48

> Power M, Guiguer K, Barton DR (2003) Effects of temperature on isotopic enrichment in Daphnia magna: implications for aquatic food-web studies. Rapid Commun Mass Spectrom 17:1619-1625

R Development Core Team (2013) R: a language and environment for statistical computing. R Foundation for Statistical Computing, Vienna

Rossi F, Colao E, Martinez MJ, Klein JC and others (2013) Spatial distribution and nutritional requirements of the endosymbiont-bearing bivalve Loripes lacteus (sensu Poli, 1791) in a Mediterranean Nanozostera noltii (Hor- 
nemann) meadow. J Exp Mar Biol Ecol 440:108-115

Sackett WM, EckelmannWR, Bender ML, Bé AWH (1965) Temperature dependence of carbon isotope composition in marine plankton and sediments. Science 148: 235-237

Santos S, Cardoso J, Carvalho C, Luttikhuizen PC, van der Veer HW (2011) Seasonal variability in somatic and reproductive investment of the bivalve Scrobicularia plana (da Costa, 1778) along a latitudinal gradient. Estuar Coast Shelf Sci 92:19-26

Sastry AN (1979) Pelecypoda (excluding Ostreidae). In: Giese AC, Pearse JS (eds) Reproduction of marine invertebrates, Vol 5. Academic Press, New York, NY

Schweimanns M, Felbeck H (1985) Significance of the occurrence of chemoautotrophic bacterial endosymbionts in lucinid clams from Bermuda. Mar Ecol Prog Ser 24:113-120

Short F, Carruthers T, Dennison W, Waycott M (2007) Global seagrass distribution and diversity: a bioregional model. J Exp Mar Biol Ecol 350:3-20

Spiro B, Greenwood PB, Southward AJ, Dando PR (1986) ${ }^{13} \mathrm{C} /{ }^{12} \mathrm{C}$ ratios in marine invertebrates from reducing sediments: confirmation of nutritional importance of chemoautotrophic endosymbiotic bacteria. Mar Ecol Prog Ser 28:233-240

Stearns SC (1992) The evolution of life histories. Oxford University Press, Oxford

Stewart FJ, Newton ILG, Cavanaugh CM (2005) Chemosynthetic endosymbioses: adaptations to oxic-anoxic interfaces. Trends Microbiol 13:439-448

Editorial responsibility: Steven Morgan,

Bodega Bay, California, USA
Taylor JD, Glover EA (2006) Lucinidae (Bivalvia): the most diverse group of chemosymbiotic molluscs. Zool J Linn Soc 148:421-438

- Tyler P, Young CM, Dolan E, Arellano SM, Brooke SD, Baker M (2007) Gametogenic periodicity in the chemosynthetic cold-seep mussel 'Bathymodiolus' childressi. Mar Biol 150:829-840

van der Geest M, van Gils JA, van der Meer J, Olff $\mathrm{H}_{\text {, }}$ Piersma T (2011) Suitability of calcein as an in situ growth marker in burrowing bivalves. J Exp Mar Biol Ecol 399:1-7

van der Heide T, Govers LL, de Fouw J, Olff $\mathrm{H}$ and others (2012) A three-stage symbiosis forms the foundation of seagrass ecosystems. Science 336:1432-1434

> van Gils JA, van der Geest M, Jansen EJ, Govers LL, de Fouw J, Piersma T (2012) Trophic cascade induced by molluscivore predator alters pore-water biogeochemistry via competitive release of prey. Ecology 93:1143-1152

van Gils JA, van der Geest M, Leyrer J, Oudman T and others (2013) Toxin constraint explains diet choice, survival and population dynamics in a molluscivore shorebird. Proc R Soc Lond B Biol Sci 280:20130861

- Warton DI, Hui FKC (2011) The arcsine is asinine: the analysis of proportions in ecology. Ecology 92:3-10

> Waycott M, Duarte CM, Carruthers TJB, Orth RJ and others (2009) Accelerating loss of seagrasses across the globe threatens coastal ecosystems. Proc Natl Acad Sci USA 106:12377-12381

Wolff WJ, Smit CJ (1990) The Banc d'Arguin, Mauritania, as an environment for coastal birds. Ardea 78:17-38

Submitted: March 18, 2013; Accepted: December 17, 2013

Proofs received from author(s): March 5, 2014 